\title{
Museologia da religião: exposições temporárias do Museu do Santuário de Fátima
}

\author{
Museology of religion: temporary exhibitions in the \\ Museum of the Shrine of Fatima
}

Maria Isabel Rocha ROQUE' (iD) 0000-0002-2258-8904

\begin{abstract}
Resumo
O ciclo de exposições temporárias organizado pelo Museu do Santuário de Fátima, no âmbito do programa de comemorações do centenário das aparições marianas, entre 2010 e 2020, permite identificar uma série de premissas inerentes à museologia do fenômeno religioso. A função catequética dessas exposições, justificada pela tutela eclesiástica do museu, é formalizada através da interpretação do santuário e dos eventos religiosos ali ocorridos, sem perda de rigor na informação prestada e confirmando a exposição como um dispositivo de comunicação e de educação não formal. A partir da observação direta das exposições que constituem o objeto de estudo deste artigo, são analisadas as tipologias narrativas, a construção da identidade visual e os modelos museográficos, cruzando os resultados com os conceitos de museologia da ideia e de descontextualização e ressignificação dos objetos (musealia), recolhidos na revisão da literatura em estudos de museu. O ciclo expositivo analisado valida o discurso museológico onde os componentes denotativos e conotativos se combinam de forma a potenciar diferentes leituras e percepções. A museografia, descrita como meta-obra do discurso expositivo de temática religiosa, é aberta, no sentido em que cria diferentes registos de informação e de interpretação dos conceitos expostos em função de um público que, embora essencialmente formado por peregrinos que visitam o santuário, é heterogêneo, com diferentes sensibilidades, crenças, interesses e conhecimentos prévios, mostrando-se eficaz, no entanto, na comunicação da mensagem de Fátima.
\end{abstract}

Palavras-chave: Comunicação. Estudos de museu. Exposição. Museografia (expografia). Objetos de museu (musealia).

\begin{abstract}
The cycle of temporary exhibitions organized by the Museum of the Sanctuary of Fátima, within the commemorative program of the Apparitions of the Virgin Mary's centenary, between 2010 and 2020, allows to identify a set of features inherent to the museology of the religious phenomenon. The catechetical function of these exhibitions, which is justified by the museum's ecclesiastical tutelage, is formalized through the interpretation of the sanctuary and of the religious events that took place there, while the accuracy of the information is guaranteed, confirming the exhibition as a non-formal education and communication device. From the direct observation of the exhibitions that are the object of this study, we analyze the narrative typologies, the visual identity, and the museographic models, crossing the results with the concepts of decontextualization and resignification of objects' (musealia), and with the museology of the idea, retrieved through the performed literature review of museum studies. The analysis of these exhibitions validates the museological discourse where denotative and connotative components are combined in order to enhance different readings and perceptions. Museography, described as a meta-work of the exhibition discourse about a religious theme, is open, as it creates different registers of
\end{abstract}

\footnotetext{
1 Universidade Europeia, Faculdade de Turismo e Hospitalidade, Unidade de Investigação em Turismo e Hospitalidade. R. Laura Ayres, 4, 1600-510, Lisboa, Portugal. Correspondência para/Correspondence to: M. I. R. ROQUE. E-mail: <maria.roque@universidadeeuropeia.pt>.

Recebido em 7 de maio de 2020, reapresentado em 16 de julho de 2020, aprovado em 8 de setembro de 2020.
}

Como citar este artigo/How to cite this article

Roque, M. I. R. Museologia da religião: exposições temporárias do Museu do Santuário de Fátima. Transinformação. v. 32, e200029, 2020. https://doi. org/10.1590/2318-0889202032e200029 
information and interpretation of the concepts, according to a heterogeneous audience, with different sensibilities, beliefs, interests, and previous knowledges, even as this public is essentially collected among the pilgrims of the sanctuary, while proving its efficiency to communicate the Message of Fatima.

Keywords: Communication. Museography. Exhibition.Museum objects (musealia). Museum studies.

\section{Introdução}

A ação de expor é uma função nuclear da prática museológica e pode ser definida como um espaço onde as coleções são mostradas e colocadas à vista do observador. As exposições são compostas de documentos ou representações de um fenômeno, de um fato ou de um conceito e ostentadas através de aparatos museográficos "como uma forma de sacralização de objetos por adoração" (Desvallées; Mairesse, 2013, p.43). Por conseguinte, a sacralidade intrínseca ao objeto religioso ou sagrado pode ser confundida com a aparente sacralização que lhe é imposta pelo museu (Roque, 2011).

A perda de sentido, associada à descontextualização, é um risco decorrente da musealização. Este risco é exponencialmente maior no caso da musealização de um objeto religioso, por envolver o sagrado, com componentes intangíveis difíceis de traduzir num discurso elaborado por objetos. Habitualmente, os objetos religiosos expostos no museu perdem o conteúdo religioso, transformando-se em obras de arte, e são valorizados pelos seus atributos materiais, formais e estéticos (Roque, 2011), numa perspectiva agnóstica ou ateia (Mairesse, 2019). O processo de musealização implica em um processo de "desfuncionalização" (Lara Filho, 2009, p.167), isso é, uma alteração da função original do objeto, a qual Ihe conferia sentido. Neste sentido aproxima-se do conceito de função-signo, segundo Roland Barthes, 1989). No museu, o objeto perde o sentido de uso para assumir um sentido representacional (Lara Filho, 2009), de acordo com a intencionalidade do discurso museológico e torna-se musealium (Brulon, 2016; Roque, 2020). Como Meneses (1994), o eixo da musealização é a transformação do objeto em documento.

Alguns autores (Mensch, 1987; Davallon, 1992; Velázquez-Marroni, 2017) propõem a distinção entre museologia do objeto e museologia da ideia. Enquanto a primeira diz respeito ao valor patrimonial, artístico ou documental do objeto, apresentado de forma isolada ou destacada dos restantes, a segunda se relaciona à mensagem; isso é, nos conceitos que se pretende transmitir. Essa distinção fundamenta as diferenças entre a museologia da arte, que seleciona o objeto em função de critérios patrimoniais e artísticos, e a museologia da religião, que promove os conceitos intangíveis inerentes ao sentido teológico, litúrgico ou devocional do objeto. Embora Meneses (1994) tenha superado a distinção entre os dois modelos, relativizando-a no sentido de que nenhum deles subsiste de forma absoluta e exclusiva, Packer e Ballantyne (2016) recuperam-na ao introduzir a experiência do visitante - tanto mais intensa quanto maior for a compreensão dos conceitos inerentes à exposição - como elemento central da museologia da ideia.

Meunier e Luckerhoff (2012) alargam o âmbito convencional da museologia,"comme dispositif de monstration, au sens restrictif de montrer et faire voir" (Meunier e Luckerhoff, 2012, p.115) para estendê-la ao campo epistemológico, "comme dispositif de communication, lieu de diffusion du savoir ou lieu d'éducation non formelle" (Meunier e Luckerhoff, 2012, p.115) o que, em certa medida, pode fundamentar a intencionalidade catequética dos museus de tutela religiosa. É a partir desses eixos conceituais que se propõe a análise museológica das exposições temporárias organizadas pelo Museu do Santuário de Fátima no âmbito do programa comemorativo do centenário das aparições.

O santuário foi estabelecido na Cova da Iria, um local ermo do concelho de Fátima, onde, em 1917, teriam acontecido as aparições da Virgem aos Três Pastorinhos, Lúcia, Francisco e Jacinta. No sítio, ainda naquele ano, foi construída a Capelinha que se mantém como fulcro do santuário. A lgreja Católica só considerou as aparições dignas de crédito em 1930, marco da aprovação eclesiástica do culto a Nossa Senhora do Rosário de Fátima. A basílica que Ihe é dedicada, na zona norte do recinto, foi sagrada em 1953. Os túmulos dos três videntes, colocados junto ao presbitério, constituem, juntamente com a Capelinha, os principais pontos da peregrinação. A basílica da Santíssima Trindade, na zona sul, já data deste século, tendo sido concluída em 2007. Todas essas construções respondem 
à necessidade de acolhimento ao número crescente de peregrinos no local e definem materialmente o espaço religioso do santuário.

O Museu do Santuário, instalado no próprio recinto, foi fundado em 1955. A exposição permanente intitulada "Fátima, Luz e Paz", evoca a memória das aparições e do local de peregrinação, além de expor parte do espólio de ex-votos ofertados pelos peregrinos. Considerando a tutela religiosa do museu, a sua localização no contexto do santuário e a missão que Ihe é implícita - apresentar e interpretar os testemunhos materiais relacionados à mensagem das aparições, à história do santuário e ao culto mariano que aqui se desenvolve -, o museu assume a intenção de sublinhar a dimensão sagrada, religiosa ou devocional dos objetos que expõe, ao mesmo tempo em que interpreta e divulga as suas componentes intangíveis, isso é, o conteúdo significante que Ihes justifica a presença no discurso expositivo. A museologia adquire, aqui, as particularidades que lhe advém da proximidade com o espaço sagrado e da afinidade com a mensagem religiosa e catequética proposta pelo santuário. Os objetos expostos circulam da esfera do sagrado para o ambiente museológico sem perder as referências de contexto e de uso que lhes conferem sentido; em contrapartida, no espaço expositivo, integram um discurso construído sobre um duplo registro científico e estético, elaborado de forma a descodificar os significados implícitos ou conotativos e a interpretá-los em função da perspectiva teológica subjacente. A par da visão canônica, as exposições incorporam as narrativas da devoção popular, permitindo "reimaginar os sujeitos dos museus" (Brulon, 2020, p.26) através da interação com os peregrinos.

Partindo de uma síntese cronológica do ciclo de exposições temporárias comemorativas do centenário das aparições, que constitui o objeto de estudo deste trabalho, e como resultado das observações realizadas, a análise crítica incide sobre o discurso museológico, a museografia enquanto meta-obra e a identidade visual.

Tomando como hipótese de partida que um ciclo de exposições organizado ao longo de uma década (20102020) permite a consolidação de uma linguagem expositiva e comunicacional focada na interpretação (Nielsen, 2017), o objetivo desta análise é identificar eventuais matrizes da museologia de religião (Roque, 2011; Minucciani, 2013; Buggeln; Paine; Plate, 2017), no caso particular dessas ocorrências em torno de um fenômeno católico e mariológico.

\section{Procedimentos Metodológicos}

Enquanto investigação no domínio das ciências sociais, o enquadramento teórico do estudo é baseado na pesquisa bibliográfica relacionada à museologia da religião. Formalizando-se como estudo qualitativo (Taylor; Bogdan, 1998; Denzin; Lincoln, 2018), de cariz descritivo na tipologia de estudo de caso (Yin, 2018), a abordagem ao objeto de estudo baseou-se no método de observação direta, não intrusiva e não participativa, das nove exposições temporárias organizadas pelo Museu do Santuário de Fátima entre 2010 e 2020. Dado tratar-se de um espaço aberto ao público, a observação foi realizada de forma autônoma a fim de evitar qualquer enviesamento da informação recolhida. Seguiu-se um modelo semiestruturado, a partir de um formulário com a identificação dos itens genéricos a serem observados: tema da exposição; estrutura do guião/percurso museográfico; caracterização da museografia e da identidade visual. A observação foi registrada em notas textuais, estruturadas em função do formulário proposto e complementadas com registos fotográficos dos percursos expositivos visitados. As observações coletadas foram, posteriormente, comparadas ao que foi visualizado nas visitas virtuais às sete primeiras exposições, uma vez que o museu não realizou visitas virtuais para as duas últimas. Sendo que o estudo abrange um arco cronológico de dez anos, o cruzamento dos dados recolhidos durante as observações iniciais com o que foi observado durante as visitas virtuais contribuiu para a consolidação da análise, conferindo-lhe uma maior uniformidade.

\section{Exposições temporárias do Museu do Santuário de Fátima}

O espaço destinado às exposições temporárias, no Convivium de Santo Agostinho, situado no piso inferior da Basílica da Santíssima Trindade, está separado do Museu do Santuário, resultando numa maior autonomia das soluções museográficas. O espaço é modulável, permitindo articular zonas e definir percursos diferentes de acordo com a particularidade dos múltiplos roteiros expositivos. 
O ciclo expositivo (Quadro 1) teve início com a exposição "Orai comigo" (1 de dezembro, 2010 - 31 de outubro, 2011), cujo itinerário temático foi inspirado pelas aparições do Anjo aos três videntes, em 1916. Seguiu-se a exposição "No trilho da luz: as aparições de Fátima" (1 de dezembro, 2011 - 31 de outubro, 2012), com o objetivo de apresentar os aspetos principais da mensagem de Fátima.

Quadro 1. Ciclo de exposições comemorativas do centenário das aparições marianas em Fátima.

\begin{tabular}{|c|c|c|c|c|c|c|c|c|}
\hline \multicolumn{7}{|c|}{ Aparições } & \multirow{3}{*}{ Capelinha } & \multirow{3}{*}{$\begin{array}{l}\text { Imagem de Nossa } \\
\text { Senhora de Fátima }\end{array}$} \\
\hline \multirow{2}{*}{ Anjo } & \multicolumn{6}{|c|}{ Virgem } & & \\
\hline & (Aparições) & $2^{a}$ aparição & 3a aparição & $4^{a}$ aparição & $5^{\mathrm{a}}$ aparição & 6a aparição & & \\
\hline Orai comigo & No trilho da luz & $\begin{array}{l}\text { Ser, o segredo } \\
\text { do Coração }\end{array}$ & $\begin{array}{l}\text { Segredo e } \\
\text { revelação }\end{array}$ & $\begin{array}{l}\text { Neste vale } \\
\text { de lágrimas }\end{array}$ & Terra e céu & $\begin{array}{c}\text { As cores do } \\
\text { sol }\end{array}$ & $\begin{array}{l}\text { Capela- } \\
\text { mundi }\end{array}$ & Vestida de branco \\
\hline
\end{tabular}

Fonte: elaborada pela autora (2020).

A partir de 2012, as exposições passaram a evocar cada uma das aparições marianas entre junho e outubro de 1917:

- "Ser, o segredo do Coração" (24 de novembro, 2012 - 31 de outubro, 2013): evocativa da aparição de junho, abriu o ciclo sob o tema do Imaculado Coração de Maria, tratado nas componentes histórica, teológica e espiritual, funcionando como uma abordagem propedêutica das exposições seguintes.

-"Segredo e revelação" (30 de novembro, 2013 - 31 de outubro, 2014): evocativa da aparição de julho, apresentou as três partes do segredo de Fátima, retomando o tema da devoção ao Imaculado Coração de Maria num percurso que levava à revelação da terceira parte do segredo, com a exposição do documento original manuscrito por Lúcia.

- "Neste vale de lágrimas" (29 de novembro, 2014 - 31 de outubro, 2015): evocativa da aparição de agosto, tomou como mote o drama vivido pelos Pastorinhos de Fátima, em meados daquele mês, como contraponto aos dramas mundiais dessa época.

- "Terra e céu: peregrinos e santos de Fátima" (28 de novembro, 2015 - 31 de outubro, 2016): evocativa da aparição de setembro, focou no tema da peregrinação na sociedade contemporânea, centrada no santuário, tendo como referência os relatos acerca da multidão que, naquele mês, acorreu à Cova da Iria, dando início a uma prática que persiste e se ampliou exponencialmente até os nossos dias.

- "As cores do sol: a luz de Fátima no mundo contemporâneo" (26 novembro, 2016 - 31 de outubro, 2018): evocativa da última aparição em outubro e do Milagre do Sol que então ocorreu. Foi a aparição mais longa, coincidindo com o ano jubilar do centenário das aparições de Fátima, e assumiu-se também como a mais ambiciosa, cujo objetivo era completar uma síntese interpretativa do fenômeno religioso em Fátima, das aparições do Anjo e da Virgem, do santuário e do culto e da devoção que aqui têm lugar.

As exposições "Capela-mundi" (1 de dezembro, 2018 - 15 de outubro, 2019) e "Vestida de branco: a imagem de Nossa Senhora do Rosário de Fátima" (30 de novembro, 2019 - 15 de outubro, 2020) foram comemorativas, respectivamente, dos centenários da construção da Capelinha das Aparições, em 1919, e da instalação da imagem de Nossa Senhora de Fátima naquele espaço, em 13 de junho de 1920. A sequência dessas exposições concebeu uma narrativa sequencial relacionada à cronologia dos acontecimentos em Fátima: as aparições do Anjo, as aparições da Virgem e, por fim, a construção da Capelinha e a instalação da imagem que lá é venerada.

\section{Descrição analítica das exposições}

\section{Discurso museológico}

O conceito de discurso é tido como suporte da narrativa, ainda que a distinção entre ambos não seja hermeneuticamente relevante. Por conseguinte, o estudo do discurso museológico fundamenta-se na análise dos seus enunciados enquanto estrutura narrativa, permitindo distinguir duas categorias-tipo (Dawson; Sykes, 2019): a 
linear, que se desenvolve de forma sequencial e cronológica é facilmente perceptível e decifrável; e a não-linear, que altera a ordem temporal e a organização espacial dos factos e dos fenômenos e é modelada de forma mais complexa e subjetiva, implicando um maior esforço de interpretação e decifração. As narrativas expositivas, concebidas como obras abertas podem articular sequências lineares e não-lineares, mas, em regra, é possível encontrar uma categoria dominante. O conceito semiológico de obra aberta remete à noção de pluralidade interpretativa. Segundo Eco (2016), os processos de "leitura" e interpretação implicam a liberdade do recetor, a quem cabe completar a obra com a sua análise pessoal.

As exposições "Orai comigo" e "As cores do sol" tipificam esses dois modelos narrativos. A exposição "Orai comigo"seguia um modelo de narrativa linear, obedecendo a um único fio condutor, elaborado de forma sequencial entre a primeira e a terceira aparição do Anjo. A exposição "As cores do sol" configurava-se como uma narrativa não linear e circular, dado que o final encontrava o começo. A exposição tinha início com um conjunto de guarda-chuvas pretos, em referência aos guarda-chuvas que os peregrinos empunhavam no dia da última aparição da Virgem que amanhecera chuvoso -, e terminava com um conjunto idêntico de guarda-sóis, agora brancos e com a efígie de Jacinta e Francisco, usados nas peregrinações atuais, no momento da comunhão dos fiéis. Essas duas peças criavam um arco narrativo, formando um círculo fechado, ao mesmo tempo em que sintetizavam a mensagem da exposição: enquanto que, à entrada, os guarda-chuvas pretos eram emoldurados numa caixa de perfil negro, no final do percurso eram brancos e a caixa-vitrine onde se encontravam era amarela, da cor do sol, tal como o painel que the servia de fundo.

Independentemente do tipo de narrativa, todas as exposições deste ciclo se enquadravam no tipo de museologia da ideia (Davallon, 1992; Mensch, 1987; Velázquez-Marroni, 2017), o que permitiu uma maior liberdade discursiva e, sobretudo, integrar objetos comuns, sem valor relevante fora do contexto expositivo. É o caso dos chapéus de chuva de uso quotidiano, já referidos na exposição "As cores do sol", das velas de cera na "Terra e Céu", ou do terço de plástico na "Capela-mundi". Este último confirmava a importância dos atributos conotativos e simbólicos como argumento de seleção de objetos para a elaboração do discurso museológico. A sua presença na exposição justificava-se pelo valor simbólico adquirido, dado tratar-se do terço com o qual rezaram, durante quase 60 horas, seis pescadores de Caxinas, no norte de Portugal, após o naufrágio da embarcação Virgem do Sameiro, em dezembro de 2011, e posteriormente oferecido como ex-voto durante a peregrinação de ação de graças realizada no mês seguinte. Para lá do seu valor patrimonial, histórico ou documental, os objetos assumiam uma função representativa, como componente integrante do discurso, cuja relevância deriva do contexto em que é inserido e das conexões que lhe são propostas.

Atendendo ao caráter inevitavelmente híbrido de uma exposição, mesmo quando esta se insere num modelo de museologia da ideia, as condicionantes de conservação e segurança podem impor um aparato museográfico convencional, centrado no objeto, isolando-o do conjunto, encerrando-o em vitrines e criando barreiras que, simultaneamente, o separam e enaltecem. No cruzamento entre ambas as categorias museológicas, a forma de expor contribui para reforçar a identidade e a relevância particular do objeto na construção do discurso.

Os objetos com valor patrimonial eram resguardados e protegidos, como as peças de ourivesaria, documentos e têxteis, objetos de pequenas dimensões ou as esculturas em madeira dourada, estofada e policromada, com atributos em prata, datadas dos séculos XVII e XVIII, que na exposição "As cores do sol"eram colocadas individualmente em vitrines verticais com campânula. Nessa exposição, um registo do coração coroado de espinhos, um pequeno adereço de cena confeccionado em cartolina e tojo por Lúcia, recebeu um tratamento museográfico idêntico, isolado sobre um plinto resguardado numa vitrine vertical inteiramente transparente devido ao seu caráter excepcional de relíquia. O caráter polissêmico dos objetos permite enquadrá-los num universo rico de conotações, estabelecendo relações semânticas entre si e com o conjunto. Por conseguinte, o mesmo objeto ganha um sentido específico e variável de acordo com o contexto em que se insere.

A obra escultórica "Jaz morto e arrefece o menino de sua mãe", de Clara Menéres, que foi apresentada pela primeira vez em 1973, na Sociedade Nacional de Belas Artes, em Lisboa, tomando como epígrafe o poema "O menino da sua mãe", de Fernando Pessoa, foi assumida como um manifesto contra a Guerra Colonial. Na exposição"Neste vale 
de lágrimas" (Figura 1), adquiriu uma conotação específica no confronto com os ex-votos a Nossa Senhora de Fátima relacionados com a Guerra Colonial, funcionando como síntese ou hiperônimo de todos os soldados, enquanto, face à representação formalmente idêntica de "Cristo morto", estabelecia uma relação simbólica de sinonímia.

O objeto podia não estar presente na sua forma original, sendo representado por substitutos ou réplicas que cumprissem uma função semântica, descritiva ou demonstrativa. Isso se sucedeu na exposição "Ser, o segredo do Coração", onde uma sequência de ampliações fotográficas explicava o processo de realização da escultura do Imaculado Coração de Maria, realizada por Thomas McGlynn, em 1958, no corpo central da fachada da basílica, a partir das indicações de Lúcia: com o hábito de religiosa Doroteia, demonstrando como se lhe manifestara o Coração Imaculado de Maria e recorrendo a uma aluna do colégio de Tui preparada pela própria vidente para servir de modelo à imagem.

Em algumas circunstâncias, o objeto podia nem ser mostrado ou representado, mas apenas sugerido, como sucedeu com a correspondência enviada à Nossa Senhora que, não sendo visível, adquiria grande densidade na exposição "Capela-mundi", onde era permitido olhar para o interior de uma sala de arquivo com as estantes repletas de caixas onde estavam guardadas as mensagens deixadas pelos peregrinos.

Na exposição "Vestida de branco" (Figura 2), a ausência da peça principal, a imagem de Nossa Senhora de Fátima em torno da qual se constrói o discurso, foi encenada de forma a acentuar a sua axialidade: uma caixa vertical, com cada uma das faces revestidas com a imagem da escultura, em tamanho natural, vista de frente no sentido do percurso expositivo e de perfil ou de costas simulando a sua instalação no interior da vitrine. Na tarde do dia 13 de junho, data do centenário da sua chegada à Cova da Iria, após as cerimônias litúrgicas do encerramento da peregrinação, a imagem esteve exposta na vitrine estendendo, de forma excepcional, a sacralidade do santuário ao espaço museológico.

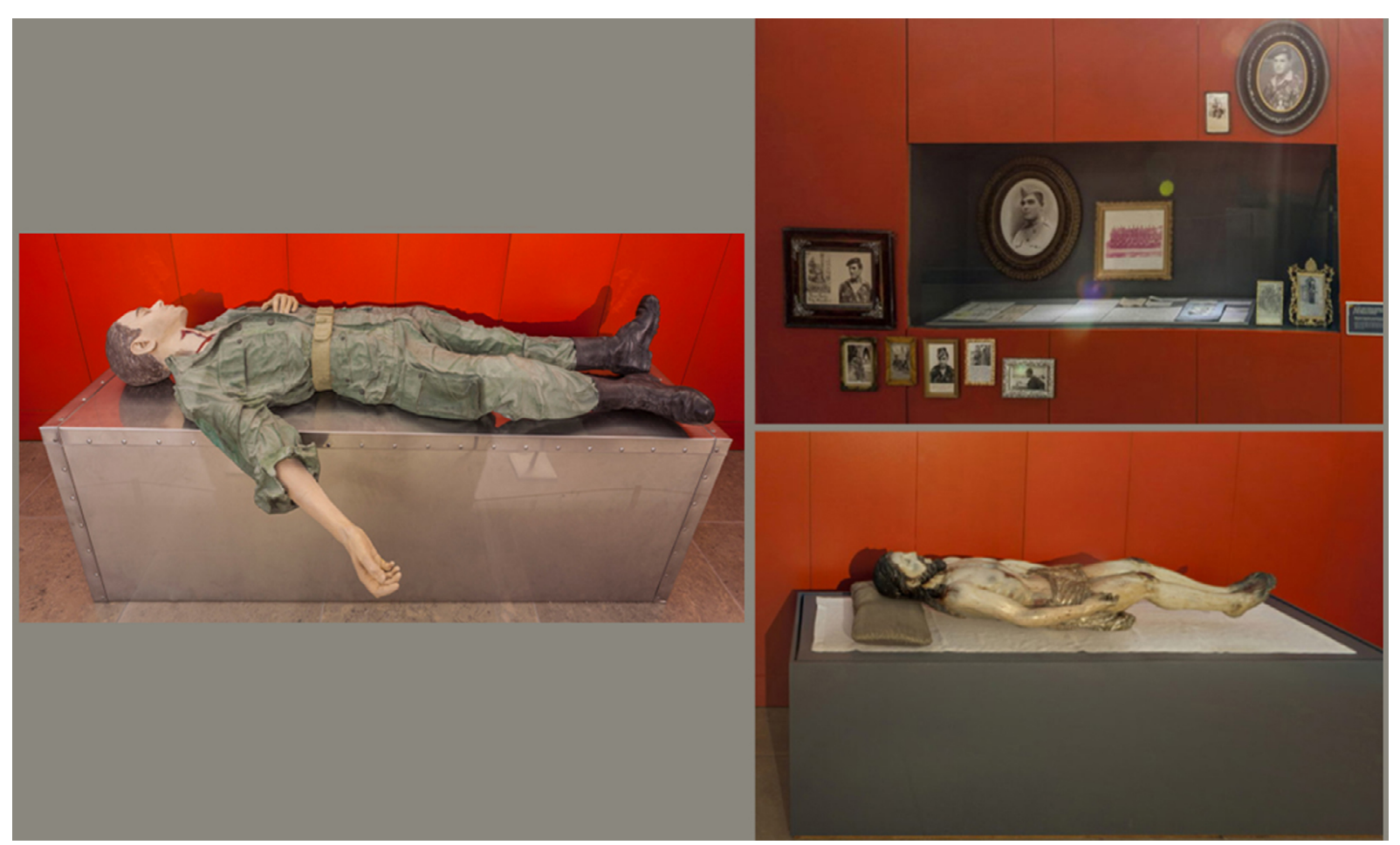

Figura 1. Fátima, exposição "Neste vale de lágrimas", 2014-2015.

Nota: "Jaz morto e arrefece o menino de sua mãe" (à esquerda); ex-votos de soldados da Guerra Colonial (à direita, em cima); Cristo morto (à direita, em baixo).

Fonte: : Museu do Santuário de Fátima (2015). Fotos do arquivo pessoal da autora. 

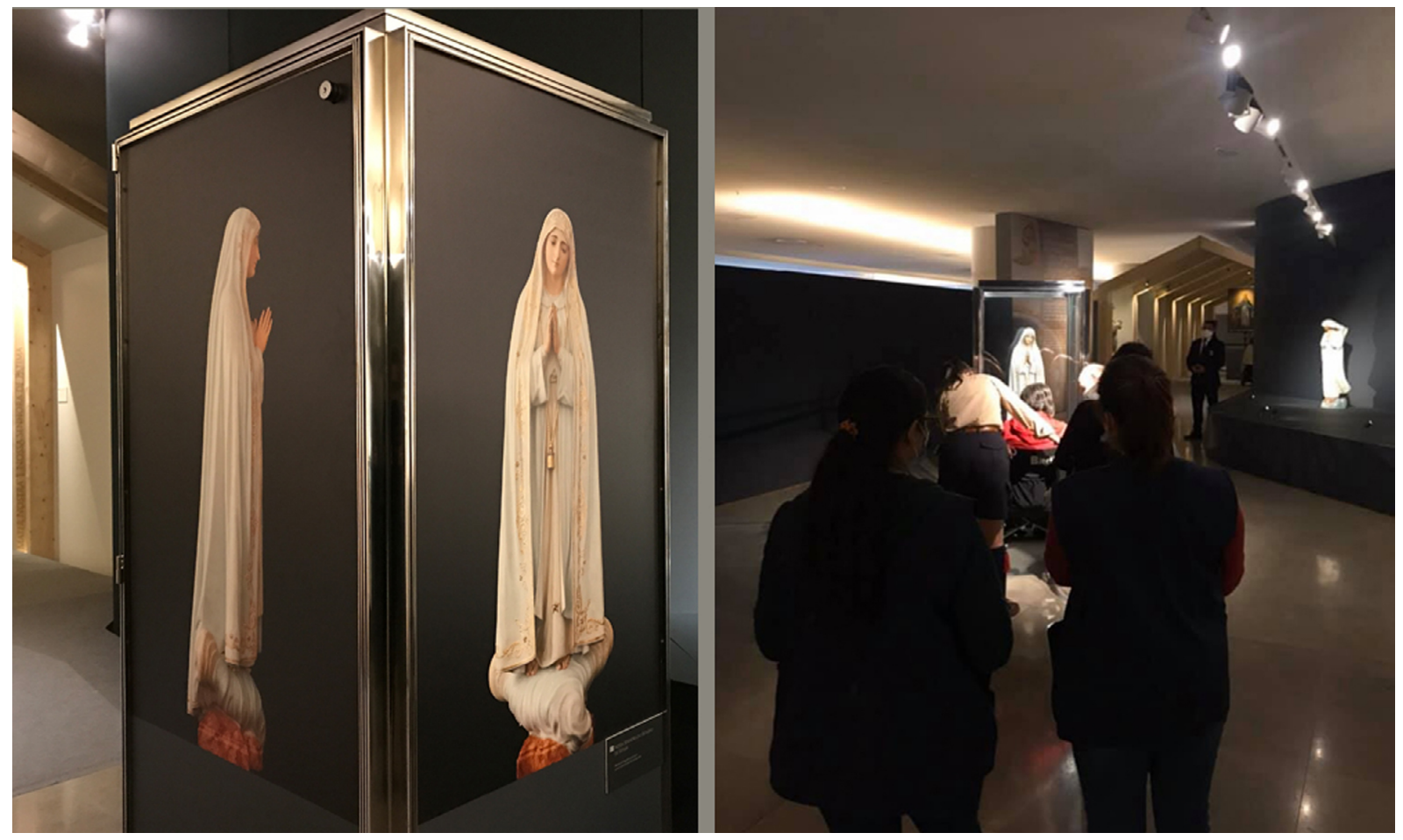

Figura 2. Fátima, exposição "Vestida de branco", 2019-2020.

Nota: Vitrine com as laterais revestidas por representações da imagem da Virgem de Fátima (à esquerda); visitantes junto à imagem exposta no dia 13 de junho de 2020.

Fonte: Museu do Santuário de Fátima (2020). Fotos do arquivo pessoal da autora à esquerda; e de Marco Daniel Duarte à direita.

Os objetos eram escolhidos por aquilo que podiam representar ou significar no âmbito da exposição, isso é, pelo contributo dado à elucidação da mensagem. Na exposição "As cores do sol", no núcleo temático do Imaculado Coração de Maria, ao lado do registo do coração coroado de espinhos feito por Lúcia, estava exposto o "Coração Independente Vermelho", de Joana Vasconcelos, com a forma de um colossal coração de Viana, peça do artesanato português, cujo efeito da filigrana é conseguido através de talheres de plástico, o qual, segundo a artista, evoca os ciclos da vida e do eterno retorno e a ambiguidade entre o luxo e a banalidade. Aqui, num núcleo expositivo sobre a linguagem do coração na última aparição de Fátima, a obra de Joana Vasconcelos ganhou uma nova conotação relacionada à devoção popular. Enquanto que na museologia do objeto religioso costuma ocorrer um processo de dessignificação, dado que o sentido do objeto é truncado através da sua apresentação como obra de arte, aqui aconteceu o contrário. Ou seja, numa situação limite, foi a obra de arte, concebida com um sentido profano, que assumiu, no discurso da exposição, um significado inteiramente religioso.

Uma situação idêntica verificou-se na exposição "Capela-mundi", com a instalação da arte contemporânea, "Anatomia da tua presença, naufragada, afogada à sombra das pétalas-ventrículos, que pulsa o nome indizível", de autoria de um artista não identificado, cujas iniciais B.S. não contrariavam a vontade expressa de manter o anonimato, datada de 2018 e constituída por uma boia salva-vidas gigante, em forma de coração e decorada com pétalas de flores, cujo caráter conceptual era lido através do confronto com os ex-votos de pescadores e com o terço de plástico dos seis náufragos de Caxinas.

Também na exposição "Vestida de branco", no último núcleo, sob o título "Uma iconografia para o mundo contemporâneo: As imagens da imagem", os objetos construíam analogias e metáforas num discurso assumidamente conotativo, descodificado através da museografia. Nas bases das vitrines ou nos painéis de suporte, um texto evidenciava o conceito associado ao objeto, como a custódia, imagem cristófora para a mulher grávida, ou o manto da rainha D. Amélia, imagem da soberana, figurando o da Virgem. O objeto é, antes de tudo, um documento (Buckland, 1991). Em paralelo, um documento, em sentido restrito arquivístico, pode funcionar como elemento axial de uma exposição. 
A exposição "Segredo e Revelação" construiu-se em torno do documento escrito por Lúcia sobre a terceira parte do segredo de Fátima e que foi mostrado ao público pela primeira vez durante a exposição (Figura 3). Lúcia escreveu-o em Tui, em 3 de janeiro de 1944, qundo ainda era religiosa Doroteia e, em 1957, o documento manuscrito deu entrada no Arquivo Secreto da Congregação para a Doutrina da Fé. O seu conteúdo foi revelado em Fátima em 13 de maio de 2000, na cerimônia de beatificação de Francisco e Jacinta, razões acrescidas para que a sua exposição fosse considerada excepcional. O documento, colocado entre duas placas transparentes, encontrava-se suspenso no interior de uma vitrine vertical, permitindo que se visse o verso e reverso das duas folhas.

O objeto-documento assume-se como musealium, termo cujo significado é "objeto de museu", atendendo à sua capacidade de significar ou de representar um conceito, onde se combinam componentes denotativos e conotativos. A definição de musealium, nos seus componentes denotativos e conotativos, retoma conceitos da teoria semiológica. Para Saussure (1916), o valor do objeto-signo resulta da relação que estabelece com os demais signos e com o contexto em que se integra. Roland Barthes (1989) retomou o conceito saussuriano de signo, aplicando-o aos objetos enquanto signos semiológicos e definiu os conceitos de denotação: a denotação, ou primeira ordem da significação, corresponde ao sentido literal em que o signo é usado no seu caráter geral, comum e objetivo; a conotação, ou segunda ordem da significação, usa o signo em sentido figurado e simbólico, expressivo, dependente com contexto em que é utilizado.

Em termos teóricos, a musealização acrescenta, ao objeto religioso, a condição de musealia, isso é, transforma-o em objeto religioso musealizado, mesmo que o peregrino que visita o museu, ou a exposição, continue a percebê-lo enquanto objeto de culto. Kenneth Hudson sintetizou essa ambivalência sumativa do objeto no museu numa frase que se tornou axiomática: "a stuffed tiger in a museum is a stuffed tiger in a museum, not a tiger" (Hudson, 1977, p.7). Numa perspectiva semiológica, os musealia, para lá da condição material de coisa física e respetivos atributos intangíveis, constituem-se como seres de linguagem (Davallon, 1992; Desvallées; Mairesse, 2013), cuja decifração, requerendo a inclusão de suportes de informação textual ou gráfica, pode ser determinada pela museografia.

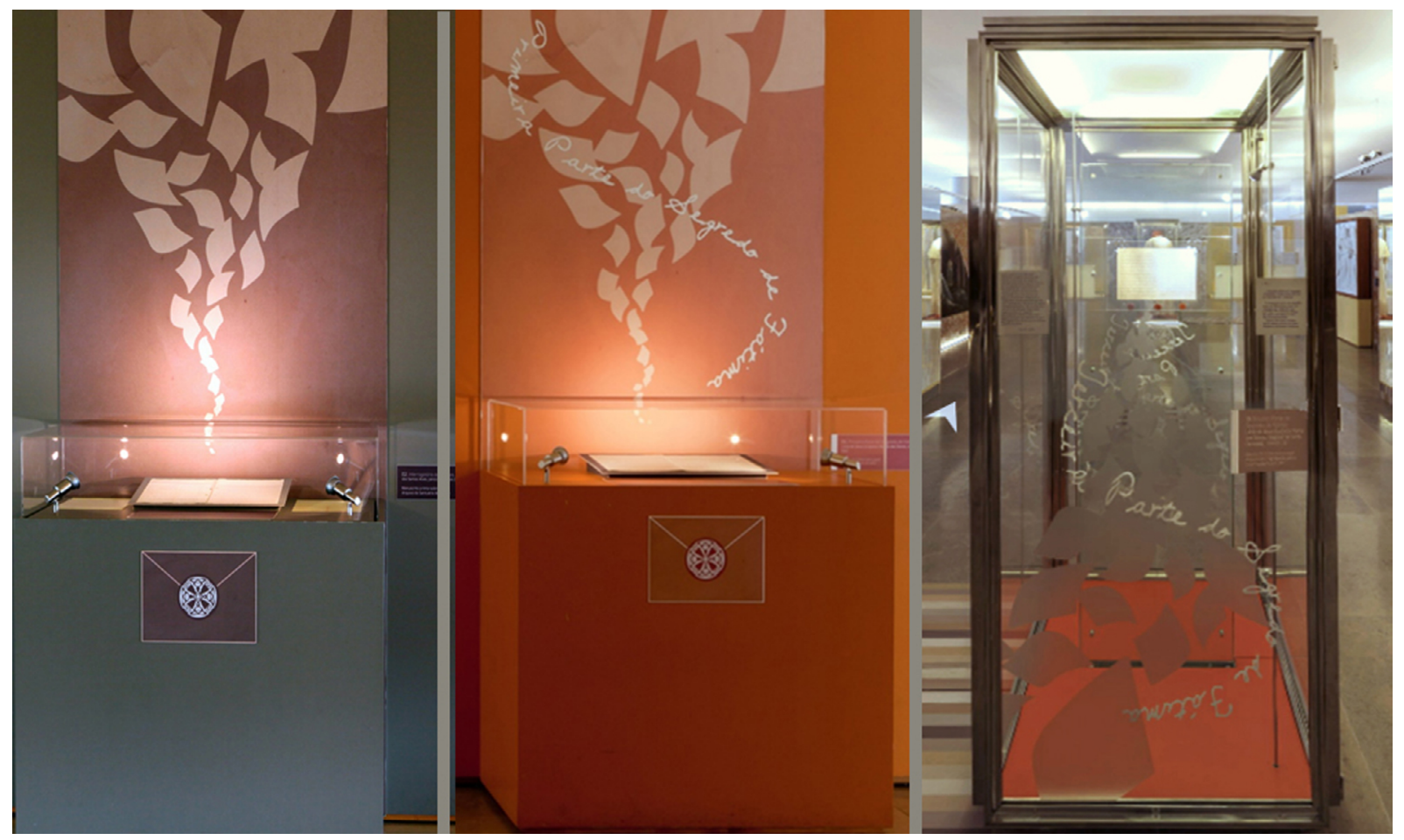

Figura 3. Fátima, exposição "Segredo e revelação", 2013-2014.

Nota: Vitrinas com os manuscritos autógrafos de Lúcia: primeira referência ao segredo (à esquerda); primeira parte do segredo (ao centro); terceira parte do segredo (à direita).

Fonte: Museu do Santuário de Fátima (2014). Fotos do arquivo pessoal da autora. 
Cada uma das exposições em análise teve uma identidade visual própria, que garantia a conformidade e coesão gráfica de todo o espaço, mas com declinações e variantes que dinamizavam o percurso expositivo. A construção da identidade visual abrangia todo o esquema gráfico, o leque cromático, a marcação dos vários núcleos, a hierarquia da informação e a própria concepção museográfica. A harmonização entre os elementos das várias peças gráficas contribuía para que o visitante-receptor tivesse uma percepção de ordem e coerência na organização da mensagem. Em regra, a identificação de cada núcleo incluía um símbolo, que se repetia nas tabelas dos objetos; um título em fontes capitulares de grande dimensão que se destacava do texto introdutório, escrito numa fonte mais reduzida; e uma imagem ou um objeto ilustrativo do respetivo conteúdo temático. A continuidade e a coerência da estrutura gráfica não impediam a presença de textos de diferentes tamanhos, ainda que, geralmente, fossem pequenos e sucintos, nem tão pouco afetavam as formalizações específicas de cada núcleo.

A identidade visual estava relacionada ao tema da exposição e funcionava como elemento contextualizador. Isso foi visível logo na primeira exposição, "Orai comigo", alusiva às aparições do Anjo. As tonalidades de verde seco da estrutura parietal e dos suportes expositivos aludiam ao ambiente natural e à época, entre a primavera e o verão, em que as aparições ocorreram. Essa alusão tornava-se mais precisa na contextualização da segunda aparição do Anjo, no verão de 1916, sobre o poço da casa dos pais de Lúcia. Aqui, as ampliações fotográficas do sítio, ainda que em preto e branco, conjugavam-se com os arbustos envasados que delimitavam o espaço e conferiam maior autenticidade à representação. A exposição "No trilho da luz", sobre as aparições do Anjo e da Virgem, assentava em tonalidades quentes e luminosas, com predominância de amarelos e dourados.

$\mathrm{Na}$ exposição "As cores do sol", o ambiente chuvoso que antecedeu o Milagre do Sol era reproduzido num túnel imersivo, onde o visitante se integrava entre a multidão representada nas ampliações fotográficas em preto e branco, feitas a partir das reportagens jornalísticas da época. A cor cinza era usada em todo o aparato expositivo, funcionando de forma eficaz como fundo de realce para as peças expostas, pontuados por breves apontamentos de cores mais intensas em alusão ao milagre.

Por sua vez, a identidade visual da exposição "Segredo e revelação" (Figura 3) definia a estrutura tripartida e hierarquizada do segredo de Fátima através da exposição dos manuscritos de Lúcia. O primeiro escrito onde Lúcia se referiu, vagamente e pela primeira vez, a um "segredo que a ninguém revelariam", encontrava-se numa vitrine de mesa, frente a um painel vertical com a representação de um motivo flamejante onde esvoaçam umas folhas de papel estilizadas. A museografia dos documentos com a revelação do segredo, embora mantivesse o esquema e o grafismo, inseria, no motivo flamejante, uma frase com a indicação do respetivo conteúdo:"primeira/ segunda/ terceira parte do segredo de Fátima". A relevância do documento com a terceira parte do segredo foi sublinhada por uma opção museográfica diferente: o documento foi colocado numa vitrine vertical em cujas paredes estava colado, em material translúcido, o elemento gráfico das folhas e a frase identificativa. Além da legenda, quatro tabelas apresentavam a transcrição de cada uma das páginas do documento, as quais estavam igualmente reproduzidas em grandes ampliações fotográficas que ocupavam toda a parede lateral. O aparato museográfico sublinhava a importância teológica do segredo no contexto das revelações privadas (Ratzinger, 2000) e do significado religioso de Fátima.

Em geral, a construção da identidade visual ultrapassava as componentes gráficas e, literalmente, estendiase a todo o espaço físico da exposição, transformando a museografia numa meta-obra que enquadrava, reforçava ou orientava o percurso expositivo, e, consequentemente, transformava-se em elemento significante. O prefixo meta pode indicar mudança ou transformação. Nesse contexto, meta-obra alude à capacidade da museografia de transformar o sentido corrente dos objetos, atribuindo-Ihes um significado específico no âmbito da exposição. Ou seja, a forma como a própria museografia é concebida determina o sentido dos objetos, pelo que se torna, ela própria, significante. Na exposição "Neste vale de lágrimas", evocativa da aparição em que a Virgem exortara à reza diária do terço, uma cadeia de contas impressa no chão e ao longo das paredes unificava graficamente o espaço e definia o percurso expositivo. 
A exposição"No trilho da luz" era percorrida por um caminho desenhado no chão, em correspondência com o título, no qual se passava pelos painéis de texto com transcrições da mensagem e conduzia à representação da Santíssima Trindade, numa analogia à quarta memória de Lúcia, transcrita no painel parietal ao lado: "[...] iluminou-se toda a Capela com uma luz sobrenatural e sobre o Altar apareceu uma Cruz de luz que chegava ao tecto, Em uma luz mais clara via-se, na parte superior da cruz, uma face de homem com corpo até à cinta, sobre o peito uma pomba também de luz e pregado na cruz, o corpo de outro homem [...]. Compreendi que me era mostrado o mistério da Santíssima Trindade" (Kondor, 2007, p.195).

Numa das salas da exposição "Ser, o segredo do Coração", um tapete gráfico conduzia à imagem do Coração de Maria e estabelecia um eixo divisor entre duas zonas temáticas, relativas às alegrias e às dores da Virgem (Figura 4). Este caminho seguia o grafismo das figurações do teto da Capela de Santo Estêvão, conhecido como o Calvário Húngaro, adjacente ao santuário de Fátima, quer no cromatismo, quer no traçado geométrico da composição. Na zona onde se encontravam representadas as alegrias da Virgem, predominavam os tons quentes, enquanto que onde estavam representadas as dores, os tons eram mais frios e acinzentados. Essa alusão era reforçada pelas legendas inscritas no tapete, como as alegrias e as dores do Coração. No início, as linhas eram horizontais, servindo de pauta à antífona da Comunhão da Missa do Imaculado Coração de Maria que se inicia com "Maria guardava todas estas palavras, meditando-as em seu coração", completando o simbolismo entre o coração de Maria e as suas dores e alegrias, estabelecido neste elemento museográfico.

Nessas exposições eram frequentes as marcações no chão, as quais estabeleciam conexões entre objetos e definiam percursos, podendo também prolongá-los para o exterior, como a mancha dourada que, na "Capela-mundi", atravessava a parede de vidro que separava o espaço expositivo do espelho de água onde um barco de pescadores, nomeado como "Stella Maris", estava em sintonia com um dos títulos da Virgem e com a designação de um dos núcleos da exposição: "Capela em alto mar: a barca de Maria".

Também na"Vestida de branco", entre as figuras recortadas que simulavam peregrinos/visitantes da exposição, no corredor de acesso à exposição, um enorme pendão fazia a ligação entre o espaço exterior, onde se estendia no

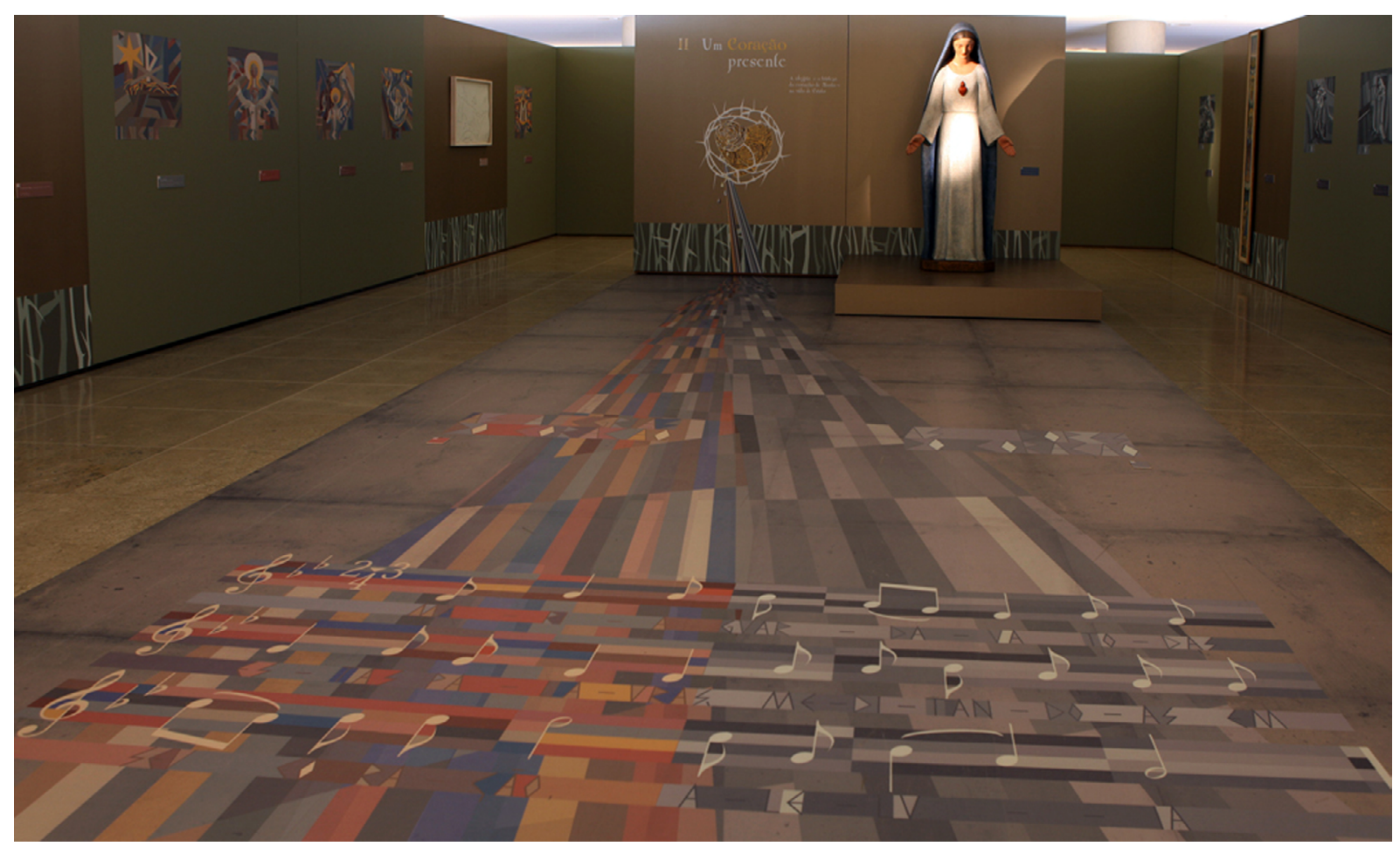

Figura 4. Fátima, exposição "Ser, o segredo do Coração", 2012-2013. Núcleo Coração de Maria: caminho e refúgio: reflexão teológica. Fonte: Museu do Santuário de Fátima (2013). Fotos do arquivo pessoal da autora. 
chão, e interior, elevando-se ao teto, numa alusão ao manto da imagem. Enquanto ligação do nível inferior ao superior, esse motivo adquiria um sentido teofânico, como síntese e símbolo do fenômeno das aparições marianas em Fátima.

A museografia foi utilizada para contextualizar objetos ou para auxiliar na identificação e compreensão da sua simbologia. Foi o caso das linhas que aludiam a um curso de água no enquadramento da pia batismal, na exposição "Terra e Céu", ou da planta da Basílica de Nossa Senhora de Fátima, sob as respetivas insígnias basilicais, na exposição "As cores do sol".

A museografia serviu também para enaltecer o valor documental e simbólico de objetos de uso comum. Na exposição "Terra e Céu", a vitrine com as velas de cera e respetivos copos, pintada de negro em referência ao ambiente noturno, inseria-se numa ampliação fotográfica da procissão das velas, sobre a qual se encontrava a partitura de "A luz de Cristo", cantada nas vigílias do santuário.

Enquanto meta-obra, a museografia torna-se expressiva e atuante. As várias exposições assumiram uma dimensão cênica e performativa, "as a site for staging, spectatorship and enactment" (Macdonald, 2012, p.283), em diferentes registros, mas focadas na comunicação multissensorial e imersiva com os públicos diversificados: do conjunto restrito dos peregrinos ao universo alargado dos turistas e outros frequentadores do santuário, em grupos homogêneos ou relativamente heterogêneos, compostos por crentes com um nível aprofundado de conhecimentos acerca do fenômeno de Fátima, por indivíduos com um conhecimento superficial, por descrentes e duvidosos do teor da mensagem de Fátima ou por eventuais visitantes totalmente extrínsecos e desconhecedores das aparições, fornecendo-Ihes diferentes registos e modalidades de informação.

\section{Conclusão}

O Museu do Santuário de Fátima define, nesse ciclo de exposições temporárias, a sua expressão e identidade, através da forma como construiu as narrativas e representou ideias e conceitos, isso é, pela exposição da intangibilidade associada aos objetos, os quais foram selecionados pelas suas competências semânticas e conotativas mais do que pelas suas valias patrimoniais e artísticas. As exposições seguiram uma abordagem conceitual e analógica ou metafórica na construção da narrativa em torno da mensagem de Fátima, o que permite defini-las como obra-aberta.

O discurso museológico, com postulados mais sugeridos do que impostos, autoriza a introdução de metáforas e alegorias através da conjugação das obras e da sua articulação com o aparato museográfico e convoca o conhecimento prévio do visitante-receptor, bem como as suas memórias individuais e coletivas face ao exposto. A comunicação torna-se mediação, dado que implica uma construção dinâmica dos conteúdos, formalizada em função da interação com o visitante o qual, em contrapartida, se assume como agente ativo do discurso museológico, produtor de significados, interpretações e conexões que o complementam e enriquecem. Por sua vez, a narrativa discursiva da exposição apropria-se das memórias, individuais e coletivas, subentendendo-as e antecipando-as para uma maior eficácia do processo comunicacional.

A análise dessas exposições permite, por conseguinte, identificar elementos distintivos da museologia de religião: a seleção dos objetos em função da sua capacidade significante e representativa; a valorização dos aspetos conotativos e simbólicos em detrimento dos atributos patrimoniais e artísticos, ainda que esses não sejam negligenciados; a utilização da museografia como recurso para evidenciar e reforçar o sentido da exposição e a elaboração de um discurso centrado na experiência do visitante.

A forma como o Museu do Santuário de Fátima elabora o discurso museológico e constrói uma museografia criativa, permite que esse discurso possa ser considerado como matriz no âmbito da museologia de religião ao anexar estratégias de interpretação e de comunicação do tema da exposição, assumindo uma função informativa e, neste caso, atendendo à tutela eclesiástica e catequética. 


\section{Referências}

Barthes, R. Elementos de semiologia. Lisboa: Edições 70, 1989.

Brulon, B. Descolonizar o pensamento museológico: reintegrando a matéria para repensar os museus. Anais do Museu Paulista: História Cultura Material, v. 28, 2020. Doi: https://doi. org/10.1590/1982-02672020v28e1.

Brulon, B. Re-interpretando os objetos de museu: da classificação ao devir. Transinformação, v. 28, n. 1, p. 107-114, 2016. Doi: http:// dx.doi.org/10.1590/2318-08892016002800009.

Buckland, M. K. Information as thing. Journal of the American Society for Information Science, v. 42, n. 5, p. 351-360, 1991.

Buggeln, G.; Paine, C.; Plate, S. B. Religion in museums: global and multidisciplinary perspectives. London: Bloomsbury, 2017.

Davallon, J. Le musée est-il vraiment un média? Publics et Musées, n. 2, p. 99-123, 1992. Doi: http://dx.doi.org/10.3406/ pumus.1992.1017.

Dawson, P.; Sykes, C. Concepts of time and temporality in the storytelling and sensemaking literatures: a review and critique. International Journal of Management Reviews, v. 21, n. 1, p. 97-114, 2019. Doi: https://doi.org/10.1111/ijmr.12178.

Denzin, N. K.; Lincoln, Y. S. The SAGE handbook of qualitative research. Thousand Oaks: Sage, 2018.

Desvallées, A.; Mairesse, F. Conceitos-chave de museologia. São Paulo: Comité Nacional Português do ICOM, 2013.

Eco, U. Obra aberta. Lisboa: Relógio d’Água, 2016.

Hudson, K. Museums for the 1980s. Paris: Unesco, 1977.

Kondor, L. Memórias da Irmã Lúcia. 13. ed. Fátima: Secretariado dos Pastorinhos, 2007.

Lara Filho, D. Museu, objeto e informação. Transinformação, v. 21, n. 2, p. 163-170, 2009. Doi: http://dx.doi.org/10.1590/S010337862009000200006.

Macdonald, S. Museums, national, postnational and transcultural identities. In: Carbonell, B. (ed.). Museum studies: an anthology of context. Chichester: John Wiley, 2012. p. 273-286.

Mairesse, F. The sacred in the prism of museology. Icofom Study Series, v. 47, n. 1-2, p. 15-22, 2019.

Meneses, U. T. B. Do teatro da memória ao laboratório da história: a exposição museológica e o conhecimento histórico. Anais do Museu Paulista: História Cultura Material, v. 2, p. 9-41, 1994.

Mensch, P. Musées en mouvement: point de vue dynamique et provocateur sur l'interaction muséologie-musées. L'icofom Studies, n. 12, p. 25-28, 1987.
Meunier, A.; Luckerhoff, J. La muséologie, champ de théories et de pratiques. Québec: Presses de l'Université du Québec, 2012.

Minucciani, V. Religion and museums: immaterial and material heritage. Torino: Allemandi, 2013.

Museu do Santuário de Fátima. Ser, o segredo do Coração - 20122013. Fátima: Museu do Santuaria de Fátima, 2013. 1 fotografia.

Museu do Santuário de Fátima. Segredo e revelação - 20132014. Fátima: Museu do Santuaria de Fátima, 2014. 1 fotografia. Museu do Santuário de Fátima. Neste vale de lágrimas - 20142015. Fátima: Museu do Santuaria de Fátima, 2015. 1 fotografia.

Museu do Santuário de Fátima. Vestida de branco - 2019-2020. Fátima: Museu do Santuaria de Fátima, 2020. 1 fotografia.

Nielsen, J. K. Museum communication and storytelling: articulating understandings within the museum structure. Museum Management and Curatorship, v. 32, n. 5, p. 440-455, 2017. Doi: https://doi.org/10.1080/09647775.2017. 1284019.

Packer, J.; Ballantyne, R. Conceptualizing the visitor experience: a review of literature and development of a multifaceted model. Visitor Studies, v. 19, n. 2, p. 128-143, 2016. Doi: http://dx.doi.or g/10.1080/10645578.2016.1144023.

Ratzinger, J. Comentário teológico. In: Congregação para a Doutrina da Fé: a mensagem de Fátima. 2000. Disponível em: http://www.vatican.va/roman_curia/congregations/cfaith/ documents/rc_con_cfaith_doc_20000626_message-fatima_ po.html. Acesso em: 26 abr. 2020.

Roque, M. I. O sagrado no museu: musealização de objectos do culto católico em contexto português. Lisboa: Universidade Católica Editora, 2011.

Roque, M. I. Sob o desígnio de Mnemosine: a preservação da memória em museus de arte. Revista Acesso Livre, v. 11, p. 7-34, 2019. Disponível em:https://revistaacessolivre.files.wordpress.com/2019/06/01_mariaisabel-roque.pdf. Acesso em: 26 abr. 2020.

Saussure, F. Cours de linguistique générale. Paris: Payot, 1916.

Taylor, B.; Bogdan T. S. Introduction to qualitative research: a guidebook and resource. New York: John Wiley, 1998.

Velázquez-Marroni, C. V. Beyond the "object-oriented vs. visitor/ idea-oriented museum" divide: the value of objects for museum experiences. Museologica Brunensi, v. 6, n. 2, p. 12-20, 2017. Doi: https://doi.org/10.5817/MuB2017-1-2.

Yin, R. K. Case study research and applications: design and methods. Thousand Oaks: Sage, 2018. 